\title{
Celebrity Endorsement and Consumer Purchase Demeanor in Benin City
}

\author{
Mrs. E. O. Odia ${ }^{1}$, Ebhote, Oseremen ${ }^{2 *}$ \\ ${ }^{1}$ Department of Business Administration. Faculty of Management and Social Sciences, University of Benin, Benin City. \\ ${ }^{2}$ Department of Business Administration, Faculty of Art, Management and Social Sciences, Edo University lyamho, Edo State.
}

* Corresponding author: ebhote.oseremen@edouniversity.edu.ng

\begin{abstract}
Celebrity endorsement is a marketing communication strategy for building and promoting brand image. Thus, the study examined celebrity endorsement and its influence on consumer purchase demeanor in Benin City, Edo state. Geographically, the study was delimited to the University of Benin, Edo state, with focus on customers of GLO network and the consumers of Pepsi-Cola within the Ugbowo and Ekehuan campuses of the institution. From the study's population, a sample size of 400 was drawn using the judgmental sampling technique. From the four hundred copies questionnaires administered, three hundred and seventy-one (371) were found usable. The study recommended that subsequent studies on celebrity endorsement should consider more industries (other than the telecommunication and beverage industries) to see if the response of celebrity endorsement with regards to consumer buying behaviour is same across industries.
\end{abstract}

Keywords: Celebrity, Purchase, Consumer, Endorsement, Network.
ARTICLE INFORMATION

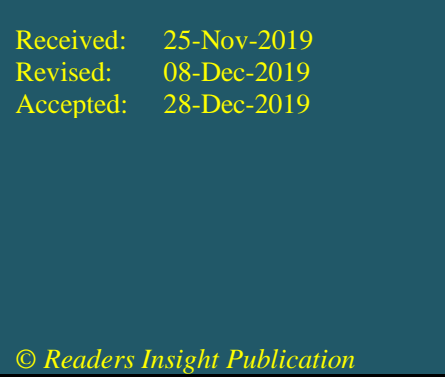

\section{INTRODUCTION}

In today's era of the ever-changing business environment, most firms if not all strive hard for their sustenance and stake in the market. With the growing advancement of technology, globalization, increasing socio-economic involvement of businesses in foreign countries and the rising political interference in corporate world, it is becoming very challenging for organizations to manage and develop their business (Bianchi \& Andrews, 2012). As such, they come up with several strategies to make optimum utilization of their resources aimed ultimately at satisfying their customers' while ensuring that they generate maximum revenue as much as possible. However, organizations cannot accomplish their objectives if they have scrawny marketing strategies (Khaniwale, 2015).

The growth rate in the Nigerian telecommunications and beverage markets has perhaps thrown up intense and cut-throat rivalry among the industry operators. In the telecommunication sector for example, the lower cost of switching from one network provider to another if dissatisfied with its service perhaps has resulted in more intense competition leading to reduction in tariff, introduction of innovative products, advertising blitz, and rising sales promotion. On the other hand, the proliferation of products in the beverage industry arguably has also heightened the competition among the concerned companies. Thus, firms within these sectors develop diverse kinds of measures to motivate and influence positive consumer purchase behaviour. One of such strategic measures according to Ohanian (1991) is the use of superstars and celebrities in advertising in order to penetrate the minds of the consumers sufficiently enough as to generate publicity and gain attention. The thrust of this marketing effort is not only to create awareness or to catch the attention of the customers, but as well as to develop appropriate positive associations between the product and the value transfer of the celebrity, influence recall and eventually induce/effect purchase decisions (Jain, 2011).
Celebrity endorsement is a marketing communication strategy for building and promoting brand image. Advertisers believe that the use of a celebrity affects advertising effectiveness, brand recall and recognition, as well as positively impact consumers' purchase attitudes towards the brand being advertised and other measures of effectiveness (Spry, Pappu \& Cornwell, 2011). There have been many studies of celebrity endorsement in recent years (Hakimi, Abedniya \& Zaeim, 2011; Hung, Chan \& Tse, 2011). These studies have examined the influence of celebrity endorsement on young adults (Hakimi et al., 2011), celebrity worship on purchase intentions (Hung et al., 2011), and the celebrity's credibility on the brand's consumer-based equity (Spry et al., 2011)

\section{Statement of Research Problem}

The study of consumer buying behaviour is perhaps a complex one as it facilitates the comprehension of such issues such as what the buyers think, what their feelings are, what are the reasons behind their decisions and how they purchase among several options. In addition, certain external and internal factors have significant influence on consumers behaviour which impact their purchasing process and eventual decision (Khaniwale, 2015). Celebrity endorsement on the other hand is not a trivial assignment considering the financial and image consequences and implications which characterise bad endorsement. Consequently, firms expend substantial attention and financial resources to attract and retain the right celebrity for their products. Poor judgment in the choice of a celebrity endorser could harm not only company sales and corporate image but also may hasten commercial failure of products in markets where morality and ethical standards are of high essence.

It appears that organizations across the different sectors of the Nigerian economy are faced with great difficulty in determining the buying behaviour of their customers. This difficulty is perhaps intensified by the growth rate within these industries which has further thrown up intense rivalry among the competing firms. The market 
being somewhat saturated, compels these firms to jostle for prospective customers, while making frantic attempts at keeping the existing customers through diverse measures and promotions one of which is having a celebrity that endorses the product(s) or service(s). Although there exist studies on celebrity endorsement and consumer buying behaviour, majority of these were conducted in advanced economies of the Western countries, with very few conducted in the developing countries of Africa, Nigeria inclusive. Thus, not many research work, particularly Nigerian studies have compared both variables of concern despite the fact that the Nigerian economy is being perceived as a potential market for celebrity endorsed products. Besides, the few studies that attempted to study celebrity endorsement and consumer buying behaviour focused on one or more firms within a particular industry. Against this backdrop therefore, this study made attempt at closing this perceived gap by investigating celebrity endorsement and consumer buying behaviour using two different firms within two dissimilar industries - that is the manufacturing/beverage industry and the service/telecommunication industry.

Against the framework of the statement of the research problem, the following research questions were stated for the study.

1. What is the relationship between celebrity's expertise and consumers buying behaviour?

2. What is the effect of celebrity's attractiveness on consumers' buying behaviour?

3. What is the effect of celebrity's trustworthiness on consumers' buying behaviour?

The overall purpose of the study is to examine how celebrity endorsement affects the consumers purchase decision. To achieve this overall purpose however, the study sought to accomplish the following specific objectives:

1. examine the relationship between celebrity expertise and consumers' buying behaviour;

2. evaluate the effect of celebrity's attractiveness on consumers' buying behaviour;

3. ascertain the effect celebrity's trustworthiness on consumers' buying behaviour;

The study formulated the following null hypothesis which could either be accepted or refuted at the end of the study.

Ho1. There is no significant relationship between celebrity's expertise and consumers' buying behaviour.

Ho2. There is no significant relationship between celebrity's attractiveness and consumers' buying behaviour.

Ho3. There is no significant relationship between celebrity's trustworthiness and consumers' buying behaviour.

In terms of subject matter, the study considered the link between celebrity endorsement and the buying behaviour of customers. Geographically, the study was delimited to the University of Benin, Edo state, with focus on customers of the GLO network and the consumers of Pepsi-Cola within the Ugbowo and Ekehuan campuses of the institution. In addition, the study being cross-sectional considered the variables of interest as at date.

\section{LITERATURE REVIEW}

\section{Concept of Celebrity Endorsement}

A celebrity is person who enjoys public recognition by a large share of a certain group of people. Friedman \& Friedman (1979) defined the term celebrity as an individual who is known to the public (actor, sports figure, entertainer, etc). That is, the achievements of the celebrity are in areas other than that of the product class endorsed (Johansson \& Sparredal, 2002). Similarly, Cyril de Run, Butt, and Yen Nee (2010) considers celebrities as "individuals who achieve a certain degree of fame across or among a section of a society; they can be actors, sports persons, politicians, or pop icons. Their fame and success allow them to inspire and influence others."

Celebrities appear in public for several reasons. They appear in public when fulfilling the demands of their profession; attending special celebrity events like movie awards; they are part of news item; fashion magazines and tabloids, provide second source of information on events of their private life; and acting as spokes people in advertising to promote products and services (Kambitis, Harahousou, \& Chatzibeir, 2002). When celebrities act as spokespersons in advertising to lend credence to product awareness and possible sales, this is referred to as celebrity endorsement. According to Ericsson and Hakansson (2005) celebrity endorser is any individual who enjoys public recognition and who uses this recognition on behalf of a consumer good by appearing with it in an advertisement.

There are various categories of celebrities. They can be categorized based work/performance area: entertainers (popstars, musicians, showmen, actors, models, etc.); sports figures, businesspersons or politicians. They could also be classified according to the level of their familiarity (local, national or international/global), and their demographics (Banytè, Stonkienè, Piligrimienè, 2011). Certain basic attributes attract marketers to the celebrities; these are beauty, talent, athleticism, power, etc) which reflect the desired attractions of the brands they endorse.

\section{Celebrity Endorsement as a Marketing Strategy}

The use of celebrity endorsers in advertisements has been considered as an effective marketing tool by advertisers and their agencies since many decades ago. Dix, Phau, and Pougnet (2010) further elaborated that the influence of a celebrity is so powerful that businesses are willing to set aside millions of dollars just on endorsement deals. This is mainly because of the celebrity's ability to capture the attention of consumers in an advertisement among the cluttered streams of messages (Kamins, 1989). The large amount of money spent by businesses is solely for the sake of hoping that it will positively influence the targeted consumers' behaviours and attitudes toward the product. The celebrity endorsement advertisement is not only capable of reaching out to the targeted consumer, but it also helps the retailer to attract a new audience. Advertisers are looking at celebrity endorsement because it is a fast and effective method to create awareness about the product. Shimp (2008) added by saying that companies investing in celebrity endorsers will only achieve profitability once the incremental revenue generated from the advertising exceeds the advertising expense.

The four brand equity dimensions as suggested by Aaker (1991) (brand awareness, brand associations, perceived quality, and brand loyalty) are important to influence consumers' perceptions that the brand purchased will bring value and benefit to the consumer (Woon, Marshall, \& Keller, 1999). Likewise, a celebrity endorser may be used in advertisements to contribute to these dimensions. Ideally, when the consumer gains satisfaction from the purchase, word-of-mouth recommendations will occur. This type of personal communication will be beneficial for retailers as it appears to be objective and unbiased (Baines, Fill, \& Page, 2008). A public figure has the power of creating a new or unknown brand to making it well-known if the endorser speaks well of the product. Brand awareness only happens when the presence of the brand has impacted the consumer's mind and when the consumer has reached his/her ability to recall the brand with ease under different conditions (Rothschild, 2001). Lear, Runyan, and Whitaker (2009) claimed that retailers can gain pre-sale demand with strong exposure of the celebrity endorser in the advertising campaigns during the months before a product is released. In other words, the endorser has already created product awareness to the consumers leading to increment in merchandise sales.

Rothschild (2001) mentioned that functional features and emotional bonds should be offered in brand associations. Similarly, a celebrity endorser is expected to project these associations to the audience. Aaker (1991) defined brand associations as the thoughts that are linked to the brand in a consumer's memory. Perceived quality refers to consumers' opinions which are subjective about a brand. Erdogan, Baker, and Tagg (2001) found out that celebrities are chosen to build a lasting impression so strong that it can persuade the consumer to make a purchase. This means that a celebrity may also enhance the brand's perceived quality, thus allowing the brand managers to charge higher prices because the consumers are willing to pay more for what they perceive as a higher quality (Shimp, 2008). According to Aaker 
and McLoughlin (2010), brand loyalty, or resistance to switching, can be based on three factors which vary from switching costs, to preference, or even a mere habit. Consumers who view the celebrity endorser as their role model are most likely to stick to the same brand which the celebrity is using. Therefore, celebrities can be considered as being able to influence the consumers to repeat the purchase. To further reinforce the statement, the endorser plays the role of making consumers less price sensitive and more loyal to the product or brand (Mela, Gupta, \& Lehmann, 1997). Kotler (2003) said that brand loyalty allows retailers to be protected from competition and generate better marketing strategies.

\section{Dimensions of Celebrity Endorsement}

Physical Attractiveness - According to Patzer (1985), physical attractiveness is an informational cue which involves effects that are subtle, pervasive, and inescapable; produces a definite pattern of verifiable differences; and transcends culture in its effects. According to Ohanian (1991), beauty is a greater recommendation than any letter of introduction. Celebrity endorser's physical attractiveness gets great social appraisal and acceptability. It is a source to capture attention of audience both in print and electronic media. Physical attractiveness has positive effect on consumer's behaviour toward the product and service while making comparison of product with the person (Ohanian, 1991). Attractiveness of celebrity produces significant results as people are themselves conscious about their own attractive looks (Kahle \& Homer, 1985). Similarly, products that are linked with a person's physical attractiveness or facial looks are much influenced by physical attractiveness of celebrity. Physically attractive celebrities are also useful for the principle of match up theory at the time of selecting celebrity where attractiveness is more influential (Kamins, 1990). Physical attractiveness is a tool to change attitude (Menon, Boone, \& Rogers, 2001). So physical attraction is a powerful source to influence the people by their look and style and create significant influence on purchase behaviour. As Nigerian celebrities like Nollywood stars, music stars, sports icons wear attention-capturing dresses in advertisements, more attention is created towards the opposite gender and such appearance makes them more attractive and easier to recall.

Credibility/Trustworthiness - Trustworthiness refers to the honesty, integrity and believability of an endorser (Erdogan et al, 2001). Consumers generally consider celebrities as trustworthy sources of communicating information (Goldsmith, Lafferty, \& Newell, 2000). It is a general principle that a person you trust a source to easily convince you to believe in an unseen thing. Thus, that individual tends to be more believed than any other in community. In addition, if such person is also an expert in the field for which he or she is advocating, it becomes more persuasive. It is supported to the extent to which the recipient sees the source as having relevant knowledge, skills, or experience and the degree to which the source gives unbiased and objective information (Belch \& Belch, 1994). In similar measures a celebrity in message of advertisement becomes really effective if it is judged that who is the speaker, who is saying; how much is that person believable? Celebrity in an advertisement with expertise is believed to be more trustworthy (Hung et al., 2011). Erdogan (1999) argued that celebrity endorser's credibility is not a single source but a valuable source having cognitive and positive effects on intention to purchase. It is trustworthiness of celebrity that also reduces the effects of rumours. An interesting factor for increasing trust in celebrity is ethnic status as confirmed by Desphande and Stayman (1994). The level of confidence reposed on celebrities similar to them on ethnic grounds is significantly high than that of endorser from any other ethnic group. It means that the celebrity that belongs to similar region, having the same lifestyle with targeted group is considered to be more credible compared to others.

Celebrity Expertise - The term expertise is defined as the extent to which a communicator is perceived to be a source of valid assertions (Hovland, Irving, \& Harold, 1953). In order to persuade recipients of information, the endorser's expertise has encouraging effect on the receiver(s) (Ohanian, 1990). Belch and Belch (1994) said that information receivers have strong belief in the person who is practical, having related knowledge and expertise in the area being advocated. An endorser with high knowledge and skills has strong power of recommendation as compared to the endorser with low expertise (Ohanian, 1990). A celebrity's expertise is one of the ways to find out his/her influence on the recipients of information (Amos, Holmes \& Strutton, 2008). If the celebrity advocating the product has strong knowledge and experience, then he/she will ultimately have influential power on the recipients due to strong believability.

\section{Celebrity Endorsement and Consumer Buying Behaviour}

Celebrity endorsement is the attachment of a popular personality of considerable reputation to a product or service by virtue of a contractual agreement between the organization and the personality (Sridevi, 2012). More often than not, organizations use advertising to communicate a celebrity's endorsement of their product, since the goal of celebrity endorsement is to guarantee the fact of the information being conveyed in an advert about a product (Amoateng \& Poku, 2013). Consumers tend to trust advertisements associated with celebrities because they are mindful of the celebrity's recognition of his/her reputation and what they stand to lose if the product being represented is inferior or does not possess the qualities claimed (Ogunsiji, 2014). Celebrity endorsement is much recognized in the marketing literature, especially at the empirical level. Invariably, there are several empirical evidences that indicate that celebrity endorsement makes a positive effect on product purchase. One of these (evidences) comes from the study of Hunter \& Davidson (2008) in which celebrity endorsement is found to cause an incremental effect on revenue generated in small and medium-size businesses. Besides, many other empirical studies (Ahmed, Ahmed \& Habiba, 2013; Boeing \& Schurhaus, 2014; Okorie, Oyedepo \& Akhidenor, 2012) confirm a positive effect of celebrity endorsement on consumers' product purchase.

Ogunsiji (2014) and Knittel and Stango (2013) confirmed that most products attached to celebrities are well patronized by consumers. This is because such products are equipped with expected quality features and therefore satisfy consumers. Similarly, Prasad (2013) and Oyeniyi (2014) have shown that celebrity endorsement positively affects product performance in terms of sales. This implies that products endorsed by celebrities are better purchased relative to those without the endorsement of celebrities. Sridevi (2012) and Okorie et al. (2012) also confirmed that a product's purchase after its endorsement by a celebrity is significantly higher than it was before endorsement. Although much empirical evidence exists on this subject, it appears like a greater number of these studies were conducted in the Western countries. Hence, a skew seems to exist in the geographical and national distribution of these studies. Academic debate on the subject in the African and Nigerian contexts appears insufficient, with little evidence on whether Nigerian celebrities influence consumers to purchase the products they endorse. Thus, it is in view of these gaps in the literature that this study fills.

\section{Conceptual Model}

Below figure illustrates the framework for understanding the effect of celebrity endorsement on consumers' purchase decision. The framework shows the integrated model for understanding celebrity endorsement and consumers' perception consumer behaviour.

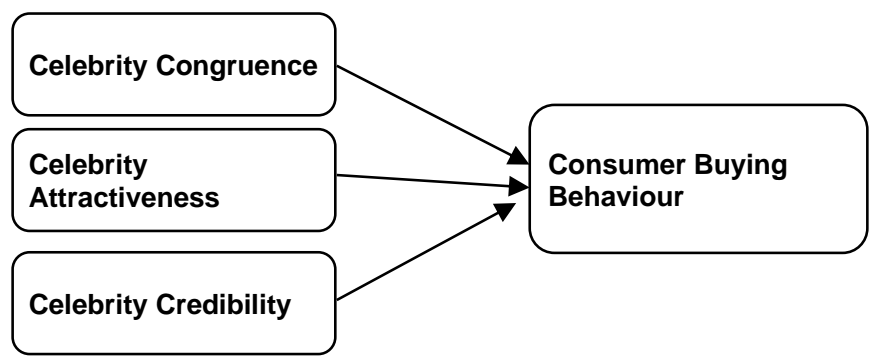

Fig. $1 \mathrm{~A}$ model of celebrity endorsement and consumer buying behaviour

Source: Adapted from (Ahmed, Seedani, Ahuja \& Paryani, 2015) 


\section{METHODOLOGY}

This study being descriptive in nature employed the use of the descriptive and correlational research design. This was considered more appropriate as it enabled obtaining data from respondents with the aid of questionnaires and asking relevant questions through scheduled interviews.

The population of the study comprised all subscribers of GLO network and consumers of Pepsi-Cola beverage domiciled within the University of Benin, Ugbowo and Ekehuan campuses, Edo State. The judgmental sampling technique, a non-probability sampling method was employed in the selection of the sample size. Hence a total of four hundred (400) respondents comprising two hundred (200) mobile phone users and two hundred (200) Pepsi-Cola consumers within the Institution was studied. This approach as affirmed by Agbonifoh and Yomere (1999) is ideal when studying a small subset of a larger population in which many members of the subset are easily identified but the enumeration of all of them would be nearly impossible. On the basis of convenience sampling, three hundred (300) and one hundred (100) respondents were selected respectively from the Ugbowo campus and Ekehuan campus of the University of Benin.

Structured questionnaire was used to obtain data from the respondents. The questionnaire consists of statements which elicited data that were analysed quantitatively. The administered Questionnaires were divided into five sections. Section A comprises questions about the biodata of the respondents while section $\mathrm{B}$ comprises questions relating to the picture and/or commercial of the celebrity endorser. Section C consists of a five-point scale Likert-type questions, ranging

from (1) which represents strongly disagree to (5) representing strongly agree. Section D comprises of questions about consumer buying behaviour towards the brands; while section E comprises questions that elicited answers about the degree of the experience of the consumer

In terms of the reliability of the instrument, the Cronbach's Alpha value for the questionnaire items include 0.82 for celebrity attractiveness tested with 5-item questions on a five-point Likert scale for accessing the physical attractiveness of celebrity and its effects on purchase bahaviour, 0.86 for trustworthiness of celebrity, 0.74 for celebrity expertise. with brand, and believability about celebrity endorsing that brand, whether celebrity is a user of that brand or not The data for this study were obtained from primary sources. Primary depository includes the various responses obtained from the respondents through a self-reporting questionnaire administered on the study sample. All collected data were analysed using the statistical package for the social sciences (SPSS). Descriptive analysis was computed using simple statistical percentages, frequency distribution tables and averages. To estimate the relationship which exists between the consumer behaviour and celebrity endorsement, a regression analysis was performed. Additionally, correlation analysis was computed in order to ascertain the degree of the relationship of celebrity endorsement on the consumer buying behaviour. All tests computations were done at $5 \%$ level of significance

\section{DATA PRESENTATION AND ANALYSES}

This section represents the degree to which the respondents filled and returned the questionnaires administered. Specifically, it captures the number of questionnaires administered, the number retrieved and analysed, all represented in percentage.

Table 1: Response rate

\begin{tabular}{lccc}
\hline & Administered & Retrieved & Percentage \\
\hline Globacom & 200 & 192 & $96 \%$ \\
Pepsi & 200 & 179 & $89.5 \%$ \\
Total & $\mathbf{4 0 0}$ & $\mathbf{3 7 1}$ & $\mathbf{9 2 . 7 5 \%}$ \\
\hline
\end{tabular}

Source: Researcher Computation, 2017
Table 1. above shows the response rate with respect to the questionnaire administered. As shown in the above table, 400 questionnaires were administered (200 each to Globacom and Pepsi customers in Benin City, Edo State, Nigeria based on random sampling technique). Out of the 400 questionnaires administered to customers of Globacom and Pepsi Cola, 192 valid questionnaires were retrieved from Globacom customers representing $96 \%$ and 179 questionnaires were retrieved from Pepsi Cola customers representing $89.5 \%$. In total, 371 out of 400 questionnaires were retrieved. This represents a combined response rate of 92.75 percent. The response rate was very satisfactory because the copies of questionnaires that were properly filled (371) were the only ones used by the researcher.

\section{Demographic Characteristics of the Respondents}

This section of the study dwells on the demographic characteristics of the respondents. Specifically, the demographic characteristics captured were sex, age marital status, educational qualification, years of patronage, employment status and level of income. See table 2 for details in the appendix.

\section{Analysis of Dependent and Independent Variables: Influence of Celebrity Endorsement on Consumer Buying Behaviour}

This section dwells on consumer buying behaviour towards advertised Glo data plan and Pepsi Cola products.

Table 3 contains the mean response of the respondents to the statements that constitute consumer buying behaviour. To the first statement in the table, the respondents were in agreement as majority of the respondents agreeing to the statement giving (mean=3.23) for Glo and (Mean = 3.19) for Pepsi Cola respondents. This means that celebrity endorser has aided the patronage for Glo data plan as well as Pepsi Cola. In like manner, the respondents from both firms agreed physical beauty of celebrity endorser for both Glo and Pepsi always attracts their attention to the advert $($ Mean=3.15) and $($ Mean $=3.42)$ for Glo and Pepsi respectively. With respect to the statement that the endorser's testimonial has helped to reduce anxiety for purchasing the product/service, while those of the Glo respondents slight disagreed (Mean $=2.94)$, the Pepsi counterpart slightly agree with the statement $($ Mean $=3.03)$. The respondents also agreed to the statement that the celebrity endorsing the product and service has helped to improve recognition for the product/service $($ Mean $=3.38)$ for Glo and $($ Mean $=$ 3.36) for Pepsi. That the celebrity endorser helps to remind the customer the need to renew/repurchase the product/service, both categories of respondents agreed to the statement $($ Mean $=3.04)$ for Glo and (mean $=3.22$ ) for Pepsi. Also, both categories of respondents agreed to the fact that the celebrity endorser gives them necessary information needed to purchase the product/service (Mean $=3.45$ ) for Glo and $($ Mean $=3.31)$ for Pepsi. The respondents in Glo category although disagree strictly with the statement that they will continue to patronize the company because of the expertise judgment of the celebrity endorsing the product while respondent from Pepsi slightly agree to the statement. With respect to the statement "I am proud to be associated with Glo Data because it is also used by the celebrity endorser" respondents from Glo slightly disagree (Mean $=2.97)$ which those of Pepsi agree (Mean = 3.36). "I am willing to recommend the product/service to other because of the sincerity of the celebrity endorser", both categories of respondent agreed with the statement (Mean $=3.05$ for Glo) and (Mean = 3.35 for Pepsi). Respondents for Glo could not pledge their loyalty with Glo data plan because of the personality and credibility of the endorser $($ Mean $=2.67$ ) while those of Pepsi respondents did pledge their loyalty because of the personality and credibility of the endorser (Mean $=3.16)$.

\section{Determinants of Celebrity Endorsers' Effectiveness: Physical Attractiveness of Glo and Pepsi Celebrity Endorser}

Table 4 on the appendix above shows responses of respondent with respect to the celebrity endorser's physical appearance. From the table, 
it is evident that for all the three statements for both categories, the respondents agreed with them. "I think Glo Data celebrity endorser would win a beauty contest any day any time" (Mean $=3.44)$ and $(3.66)$ for Glo and Pepsi respectively. For the statement "the physical attractiveness of Glo Data celebrity endorser always makes me listen to the adivert" (Mean = 3.61) and $($ Mean $=3.63$ ) for Glo and Pepsi respectively. With respect to the statement that the respondent would like to look like the endorser, $($ Mean $=3.42)$ and $($ Mean $=3.46)$ for Glo and Pepsi respectively.

\section{Trustworthiness of Glo/Pepsi Celebrity Endorser}

Table 5 on appendix shows responses of respondent with respect to the celebrity endorser's trustworthiness. From the table, it is evident that for all the three statements for both categories, the respondents agreed with them as each of the mean values is greater than 3.0, the cut-off point. For the statement "I think the above celebrity endorser is highly credible" and (3.56) for both categories of respondents. For the statement "I believe every word about Glo Data spoken by the above celebrity endorser" (Mean = 3.14) and (Mean = 3.16) for Glo and Pepsi respectively. With respect to the statement "I accept words of endorsement from my favorite celebrity as a testimonial", $($ Mean = 3.16) and (Mean = 3.36) for Glo and Pepsi respectively. To the statement "I think the advertisement message by the celebrity endorser is sincere" $($ Mean $=3.30)$ for Glo respondents and $($ Mean $=3.43)$ for Pepsi respondents. The last statement on celebrity's trustworthiness, both categories agreed with the celebrity endorser is trustworthy. $($ Mean $=3.44)$ for Glo respondents and $($ Mean $=3.43)$ for Pepsi respondents.

\section{Perceived Expertise of Glo/Pepsi Celebrity Endorser}

Table 6 on the appendix shows responses of respondents with respect to the celebrity endorser's expertise. From the table, it is evident that for all the three statements for both categories, the respondents agreed with them as each of the mean values is greater than 3.0, the cut-off point. With respect to the statement "I value the experience of the celebrity endorser" (Mean $=3.55)$ for Glo respondents and (Mean =3.61). Majority of the respondents from both categories also believe that their respective celebrity endorsers has good knowledge of the brand being endorsed (Mean $=3.64)$ and $($ Mean $=3.86$ ) respective for Glo and Pepsi. The respondents also believe that the endorser has the required expertise to advertise the brand (Mean $=3.80$ ) and $(3.86)$ respective for Glo and Pepsi. On the last statement on celebrity expertise, majority of the respondents also demonstrated that the endorser has the right skills to advise the brand (Mean = 3.82) and (Mean $=3.93$ ) for Glo and Pepsi respectively.

\section{Impact of Celebrity Endorsement on consumer Buying Behaviour}

The value of $R^{2}$ which is 0.352 indicates that the independent variables (physical attractiveness, celebrity expertise, celebrity trustworthiness, celebrity respect and celebrity congruence) explain only $35.2 \%$ of the variation of the dependent variable (consumer buying behaviour) leaving $64.8 \%$ unaccounted for. This figure further reduces to about .343 (34.3\%) when the R-squared statistics is further adjusted. This means that other factors apart from the independent. The F statistic of 39.614 is significant at 0.05 . This means that there is a statistically significant relationship between the consumer buying behaviour and celebrity expertise, physical attractiveness, celebrity trustworthiness, celebrity congruence and celebrity respect. Based on the p-value of the variable under consideration, we therefore, reject $\mathrm{H}_{\mathrm{o}}$ in hypothesis 1 and 2, in hypothesis $3 \mathrm{H}_{\mathrm{o}}$ was retained because their $\mathrm{p}$ value was greater than 0.05 . Details contained in table 7 .

\section{Discussions of Findings}

This study proposes several specific relationships between celebrity endorsement dimensions and consumer buying behaviour, adapted from reviews of relevant research, in application to a real sample. The results indicate that celebrity endorsement dimensions help determine consumer buying behavior with the exceptions of celebrity expertise and celebrity congruence. Thus if a manufacturing firm wants to evaluate how the behaviour of her target market market is influenced, the managers should recognize the relevant celebrity endorsement dimensions like physical attractiveness, celebrity trustworthiness and celebrity respect) and use the likely predicted level of efficiency and restrictions to assess and develop effective consumer behaviour. By investigating the influence of celebrity endorsement dimensions on consumer buying behaviour, this study confirms that physical attractiveness, celebrity trustworthiness and celebrity respect positively and significantly influence consumer buying behaviour. This is in consistence with the findings of Aaker and McLoughlin (2010), Mela, Gupta, and Lehmann (1997) and Hung et al., (2011).

The study further found that celebrity expertise and celebrity congruence do not significantly influence consumer buying behaviour. This however contradicts some of the previous studies (including Amos, Holmes \& Strutton, 2008; Misra \& Beatty, 1990; Kamins \& Gupta, 1994) conducted on the subject matter which suggest some positive and significant relationship between the celebrity endorsement dimensions and consumer buying behaviour. According to those previous studies, product is easily recalled, and affect is improved by the similarity between source endorser and the brand. Therefore, when a product or service is in congruence with the celebrity, positive consumer buying behaviour is guaranteed.

\section{CONCLUSIONS AND RECOMMENDATIONS}

This study focused on celebrity endorser and consumer buying behavior in Benin City. The study has attempted to identify the components of celebrity endorsement (celebrity expertise, physical attractiveness, celebrity trustworthiness, celebrity congruence and celebrity respect and its influence on consumer buying behaviour in Benin City. Based on the results obtained, we conclude that celebrity expertise has no significant influence on consumer buying behaviour; physical attractiveness significantly influences consumer buying behaviour; celebrity trustworthiness has significant influence on consumer buying behaviour; celebrity congruence does not have significant effect on consumer buying behaviour and celebrity respect has significant relationship with consumer buying behaviour. We therefore recommend as follows:

1. We recommend that future studies of this kind should be undertaken in other states of the Federation thereby giving deeper insights into the subject matter.

2. More so, the study has also restricted itself to two industries (telecommunication and Fast-Moving Consumable Goods [FMCG]). It is thus recommended that subsequent studies on same or similar subject matter should incorporate more industries to see if the behavior of celebrity endorsement with respect to consumer buying behavior is same across industries.

3. The study has empirically examined the relationship that exist celebrity endorsement and consumer buying behaviour in Benin City. The study therefore recommends that firms should give more attention to celebrity respect when studying celebrity endorsement with respect to consumer buying behaviour.

\section{REFERENCES}

Aaker, D. A. (1991). Managing brand equity: Capitalizing on the value of a brand name. New York, NY: The Free Press.

Aaker, D. A., \& McLoughlin, D. (2010). Strategic market management: Global perspectives. Barcelona, Spain: John Wiley and Sons.

Agbonifoh, B. A., \& Yomere, G. O. (1999). Research methodology in the management and social sciences. Benin City: Uniben Press.

Ahmed, W., Ahmed, S. \& Habiba, U. (2013). Celebrity launched products effect on consumers in recession. Middle-East Journal of Scientific Research, 17(8), 1105-1124. 
Amoateng, F., \& Poku, K. (2013). The impact of advertisement on alcohol consumption: A case study of consumers in Bantama Sub-Metro International Review of Management and Marketing, 3(1), 28-36.

Amos, C., Holmes, G., \& Strutton, D. (2008). International Journal of Advertising, 27(2), 209-234.

Baines, P., Fill, C., \& Page, K. (2008). Marketing. New York: Oxford University Press.

Banyte, J., Stonkienè, E., \& Piligrimienè, Z. (2011). Selecting celebrities in advertising: The case of Lithuanian sports celebrity in non sport product advertisement. Economics and Management, 16, 1215-1224.

Belch, G., \& Belch, M., (1994). Introduction to advertising and promotion: An integrated marketing communications perspective (3rd ed.). Irwin: Homewood, 189-192.

Bianchi, C., \& Andrews, L. (2012). Risk, trust, and consumer online purchasing behaviour: A Chilean perspective. International Marketing Review, 29(3), 253-275.

Boeing, R., \& Schurhaus, C. (2014). The effect of celebrity endorsement on brazilian consumer behaviour: does it really matter? International Business Research, 7(5), 49-61.

Cyril de Run, E., Butt, M., \& Yen Nee, C. (2010). The influence of role models on young adults purchase. Journal Kemanusiaan bil.15 Jun 2010.

Desphande, R., \& Staymaa D. (1994). A tale of two cities: Distinctiveness theory and advertising effectiveness. Joumal of Marketing Research, 31(1), 57-64.

Dix, S., Phau, I., \& Pougnet, S. (2010). Bend it like beckham: The influence of sports celebrities on young adult consumers. Young Consumers: Insight and Ideas for Responsible Marketers, 11(1), 36 - 46.

Erdogan, Z. B. (1999). Celebrity endorsement: A literature review. Journal of Marketing Management, 14, 291-314.

Erdogan, Z. B., Baker, M., \& Tagg, S. (2001). Selecting celebrity endorsers: The practitioner's perspective. Journal of Advertising Research, 41(3), $39-48$

Ericsson, L., \& Hakansson, E. (2005). Athletes as celebrity endorsers: Case studies from Sweden.

Friedman, H. H., \& Friedman, L. (1979). Endorser effectiveness by product type. Journal of Advertising Research, 19(3), 63-71.

Goldsmith, R.E., Lafferty, B.A., \& Newell, S. J. (2000). The impact of corporate credibility and celebrity credibility on consumer reaction to advertisements and brands. Journal of Advertising, 29(3), 43-54.

Hakimi, B. Y., Abedniya, A., \& Zaeim, M. N. (2011). Investigate the impact of celebrity endorsement on brand images. European Journal of Scientific Research, 58(1), 116-132.

Hovland, C., Irving, J., \& Harold, K. (1953). Communication and persuasion: Psychological studies of opinion change. New Haven, CT: Yale University Press.

Hung, K., Chan, K. W., \& Tse, C. H. (2011). Assessing celebrity endorsement effects in China: A consumer-celebrity relational approach. Journal of Advertising Research, 51(4), 608623.

Jain, V. (2011). Celebrity endorsement and its impact on sales: A research analysis carried out in India. Global Journal of Management and Business Research, 11(4), 69-84.

Johansson, J., \& Sparredal, J. (2002), Celebrity endorsements: A case study of Axa and the Ludmila Engquist incident, Lulea University of Technology, Sweden. Available at: http://www.epubl.ltu.se.

Kahle, L. R., \& Homer, P. M. (1985). Physical attractiveness of the celebrity endorser: A social adaptation perspective. Journal of Consumer Research, 11(4), 954-961. Retrieved from http://www.jstor.org/stable/2489220
Kambitis, C. Y., Harahousou, N. T., \& Chatzibeir, G. (2002). Sports advertising in print media: The case of 2000 Olympic games. Corporate communication: An International Journal, 7(3), 155-161.

Kamins, M. A. (1989). Two-sided versus one-sided celebrity endorsements: The impact on advertising effectiveness and credibility. Journal of Advertising, 18(2), 4-10

Kamins, M. A. (1990). An investigation of the match-up hypothesis in celebrity advertising: When beauty may be only skin deep. Journal of Advertising, 19(1), 4-13.

Knaniwale, M. (2015). Consumer buying behaviour. International Journal of Innovation and Scientific Research, 14(2), 278-286

Knittel, C. R., \& Stango, V. (2013). Celebrity endorsements, firm value, and reputation risk: Evidence from the Tiger Woods scandal. Articles in Advance, 2, 1-17.

Kotler, P. (2003), Marketing management $\left(11^{\text {th }}\right.$ ed.). Indian: Pearson Education.

Lear, K. E., Runyan, R. C., \& Whitaker, W. H. (2009). Sports celebrity endorsements in retail products advertising. International Journal of Retail \& Distribution Management, 37(4), 308 - 321.

Mela, C. F., Gupta, S., \& Lehmann, D. R. (1997). The long-term impact of promotion and advertising on consumer brand choice. Journal of Marketing Research, 34(2), 248-261.

Menon, M. K., Boone, L. E., \& Rogers, H. P. (2001). Celebrity advertising: An assessment of its relative effectiveness. Unpublished thesis, University of Southern Alabama.

Ogunsiji, S. A. (2014). The impact of celebrity endorsement on strategic brand management. International Journal of Business and Social Science, 3(6) 141-145.

Ohanian, R. (1990). Construction and validation of a scale to measure celebrity endorsers, perceived expertise, trustworthiness, and attractiveness. Journal of Advertising, 19, 3952

Okorie, N., Oyedepo, T., \& Akhidenor, G. (2012). The dysfunctional and functional effect of celebrity endorsement on brand patronage, Online Journal of Communication and Media Technologies, 2(2), 141-52.

Oyeniyi, O. (2014). Celebrity endorsements and product performance: A study of nigerian consumer markets. Management \& Marketing, 7(1), 42-51.

Patzer, G. L. (1985). Source credibility as a function of communicator physical attractiveness. Journal of Business Research, 11(2), 229-241.

Prasad, C. S. J. (2013). Brand endorsement by celebrities impacts towards customer satisfaction. African Journal of Business Management, 7(35), 3630-3635.

Rothschild, M. L. (2001). Book review: Building strong brands. Viewed 31 January 2011, available at http://smquarterly.com/archive/Vol\%20VII(2)/VII 2 e BuildingStron gBrands.pdf.

Shimp, T. A. (2008). Advertising, promotion, and other aspects of integrated marketing communications ( $8^{\text {th }}$ ed.). Canada: Cengage Learning.

Spry, A., Pappu, R., \& Cornwell, T. B. (2011). Celebrity endorsement, brand credibility and brand equity. European Journal of Marketing, 45(6), 882 909.

Sridevi, J. (2012). Effectiveness of celebrity endorsement in brand recall and brand recognition. International Journal of Business Economics \& Management Research, 2(5), 203-209.

Woon, B. N., Marshall, R., \& Keller, K. L. (1999). Measuring brand power: Validating a model for optimizing brand equity. Journal of Product \& Brand Management, 8(3), $170-184$

\section{Appendix}

Table 2: Demographic Characteristics of respondents

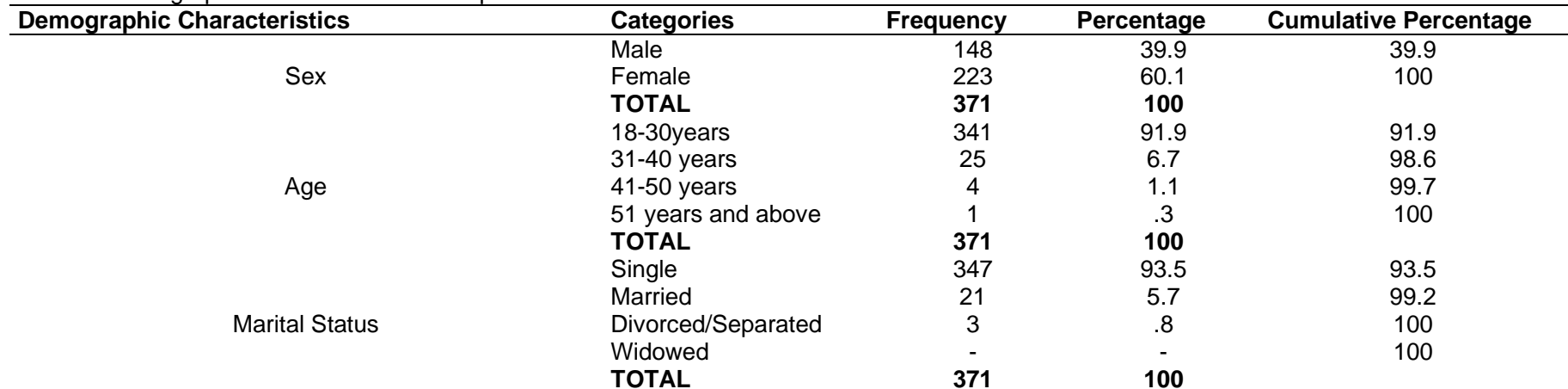




\begin{tabular}{|c|c|c|c|c|}
\hline & SSCE/GCE & 214 & 57.7 & 57.7 \\
\hline & OND/NCE & 58 & 15.6 & 73.3 \\
\hline \multirow[t]{5}{*}{ Educational qualification } & HND/BSc. & 81 & 21.8 & 95.1 \\
\hline & MSc. And others & 18 & 4.9 & 100 \\
\hline & TOTAL & 371 & 100 & \\
\hline & Below 5 years & 155 & 41.8 & 41.8 \\
\hline & $5-10$ years & 97 & 26.1 & 67.9 \\
\hline \multirow[t]{4}{*}{ Years of patronage } & $11-15$ years & 39 & 10.5 & 78.4 \\
\hline & 16 years and above & 80 & 21.6 & 100 \\
\hline & TOTAL & 371 & 100 & \\
\hline & Unemployed & 276 & 74.4 & 74.4 \\
\hline \multirow{5}{*}{ Employment status } & Employed & 25 & 6.7 & 81.1 \\
\hline & Self-employed & 70 & 18.8 & 100 \\
\hline & TOTAL & 371 & 100 & \\
\hline & $18,000-30,999$ & 172 & 46.4 & 46.4 \\
\hline & $31,000-50,999$ & 88 & 23.7 & 70.1 \\
\hline \multirow{4}{*}{ Level of income $(\mathrm{N})$} & $51,000-100,999$ & 30 & 8.1 & 78.2 \\
\hline & $101,000-200,000$ & 6 & 1.6 & 79.8 \\
\hline & Others & 75 & 20.2 & 100 \\
\hline & TOTAL & 371 & 100 & \\
\hline
\end{tabular}

Source: Researcher's Computation, 2017

Table 3: Consumer Behaviou

\begin{tabular}{|c|c|c|c|c|c|c|c|c|c|c|c|c|}
\hline \multirow[b]{2}{*}{ Statement } & \multicolumn{2}{|c|}{ SD } & \multicolumn{2}{|c|}{ D } & \multicolumn{2}{|c|}{$U$} & \multicolumn{2}{|c|}{ A } & \multicolumn{2}{|c|}{ SA } & \multirow[t]{2}{*}{ Mean } & \multirow[t]{2}{*}{ Std Dev. } \\
\hline & Freq & $\%$ & Freq & $\%$ & Freq & $\%$ & Freq & $\%$ & Freq & $\%$ & & \\
\hline $\begin{array}{l}\text { The celebrity endorser has aided my patronage for } \\
\text { Glo data plan }\end{array}$ & 31 & 16.1 & 37 & 19.3 & 42 & 21.9 & 49 & 25.5 & 32 & 16.7 & 3.23 & 2.597 \\
\hline $\begin{array}{l}\text { The celebrity endorser has aided my patronage for } \\
\text { Pepsi Cola }\end{array}$ & 31 & 17.3 & 29 & 16.2 & 20 & 11.2 & 73 & 40.8 & 26 & 14.5 & 3.19 & 1.348 \\
\hline $\begin{array}{l}\text { The physical beauty of the celebrity endorser for } \\
\text { Glo Data always attracts my attention to the advert } \\
\text { The physical beauty of the celebrity endorser for }\end{array}$ & 34 & 17.7 & 36 & 18.8 & 22 & 11.5 & 67 & 34.9 & 33 & 17.2 & 3.15 & 1.385 \\
\hline $\begin{array}{l}\text { Pepsi Cola always attracts my attention to the } \\
\text { advert }\end{array}$ & 21 & 11.7 & 20 & 11.2 & 29 & 16.2 & 81 & 45.3 & 28 & 15.6 & 3.42 & 1.221 \\
\hline $\begin{array}{l}\text { The Endorser's testimonial about Glo Data has } \\
\text { helped to reduce my anxiety for purchasing data } \\
\text { plan }\end{array}$ & 28 & 14.6 & 46 & 24 & 46 & 24 & 54 & 28.1 & 18 & 9.4 & 2.94 & 1.218 \\
\hline $\begin{array}{l}\text { The Endorser's testimonial about Pepsi Cola has } \\
\text { helped to reduce my anxiety for purchasing Pepsi } \\
\text { Cola }\end{array}$ & 29 & 16.2 & 35 & 19.6 & 33 & 18.4 & 65 & 36.3 & 17 & 9.5 & 3.03 & 1.263 \\
\hline $\begin{array}{l}\text { The celebrity endorsing Glo Data has helped to } \\
\text { improve my recognition of Glo Data plan }\end{array}$ & 22 & 11.5 & 31 & 16.1 & 26 & 13.5 & 79 & 41.1 & 34 & 17.7 & 3.38 & 1.268 \\
\hline $\begin{array}{l}\text { The celebrity endorsing Pepsi Cola has helped to } \\
\text { improve my recognition of Pepsi Cola }\end{array}$ & 28 & 15.6 & 20 & 11.2 & 22 & 12.3 & 78 & 43.6 & 31 & 17.3 & 3.36 & 1.322 \\
\hline $\begin{array}{l}\text { The celebrity endorser for Glo Data reminds me of } \\
\text { the need to renew my Glo Data plan }\end{array}$ & 27 & 14.1 & 42 & 21.9 & 40 & 20.8 & 62 & 32.3 & 21 & 10.9 & 3.04 & 1.244 \\
\hline $\begin{array}{l}\text { The celebrity endorser for Pepsi Cola reminds me } \\
\text { of the need to renew my Pepsi Cola }\end{array}$ & 25 & 14 & 30 & 16.8 & 32 & 17.9 & 65 & 36.3 & 27 & 15.1 & 3.22 & 1.286 \\
\hline $\begin{array}{l}\text { The celebrity endorser for Glo Data gives me all the } \\
\text { necessary information needed to purchase the } \\
\text { right data plan }\end{array}$ & 25 & 13 & 22 & 11.5 & 24 & 12.5 & 84 & 43.8 & 37 & 19.3 & 3.45 & 1.285 \\
\hline Total & & & & & & & & Pep & & & $\begin{array}{l}3.02 \\
3.25\end{array}$ & \\
\hline
\end{tabular}

Source: Author Computation, 2017

Table 4: Physical Attractiveness of Glo data/Pepsi Celebrity Endorser

\begin{tabular}{|c|c|c|c|c|c|c|c|c|c|c|c|c|}
\hline 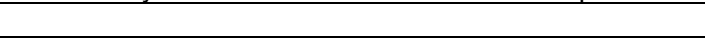 & \multicolumn{2}{|c|}{ SD } & \multicolumn{2}{|c|}{ D } & \multicolumn{2}{|c|}{$\mathbf{U}$} & \multicolumn{2}{|c|}{$\mathbf{A}$} & \multicolumn{2}{|c|}{ SA } & \multirow[b]{2}{*}{ Mean } & \multirow[b]{2}{*}{ Std Dev. } \\
\hline Statement & Freq & $\%$ & Freq & $\%$ & Freq & $\%$ & Freq & $\%$ & Freq & $\%$ & & \\
\hline $\begin{array}{l}\text { I think Glo Data celebrity endorser would win a beauty } \\
\text { contest any day any time }\end{array}$ & 9 & 5 & 31 & 16 & 46 & 24 & 78 & 41 & 28 & 15 & 3.44 & 1.072 \\
\hline $\begin{array}{l}\text { I think Pepsi Cola celebrity endorser would win a beauty } \\
\text { contest any day any time }\end{array}$ & 10 & 6 & 15 & 8 & 31 & 17 & 93 & 52 & 30 & 17 & 3.66 & 1.034 \\
\hline $\begin{array}{l}\text { The physical attractiveness of Glo Data celebrity } \\
\text { endorser always makes me listen to the advert. }\end{array}$ & 13 & 7 & 22 & 12 & 30 & 16 & 89 & 46 & 38 & 19.8 & 3.61 & 1.130 \\
\hline $\begin{array}{l}\text { The physical attractiveness of Pepsi Cola celebrity } \\
\text { endorser always makes me listen to the advert. }\end{array}$ & 10 & 6 & 22 & 12 & 19 & 11 & 102 & 57 & 26 & 14.5 & 3.63 & 1.054 \\
\hline $\begin{array}{l}\text { Many people would like to look like Glo Data celebrity } \\
\text { endorser }\end{array}$ & 15 & 8 & 34 & 18 & 37 & 19 & 68 & 35 & 38 & 20 & 3.42 & 1.212 \\
\hline $\begin{array}{l}\text { Many people would like to look like Pepsi Cola celebrity } \\
\text { endorser }\end{array}$ & 22 & 12 & 15 & 8 & 28 & 16 & 86 & 48 & 28 & 15.6 & 3.46 & 1.214 \\
\hline Total & & & & & & & & & & & $\begin{array}{l}3.49 \\
3.58\end{array}$ & \\
\hline
\end{tabular}


Table 5: Trustworthiness of Glo/Pepsi Celebrity Endorser

\begin{tabular}{|c|c|c|c|c|c|c|c|c|c|c|c|c|}
\hline & \multicolumn{2}{|c|}{ SD } & \multicolumn{2}{|c|}{ D } & \multicolumn{2}{|c|}{$\mathbf{U}$} & \multicolumn{2}{|c|}{ A } & \multicolumn{2}{|c|}{ SA } & \multirow[b]{2}{*}{ Mean } & \multirow[b]{2}{*}{ Std Dev. } \\
\hline Statement & Freq & $\%$ & Freq & $\%$ & Freq & $\%$ & Freq & $\%$ & Freq & $\%$ & & \\
\hline $\begin{array}{l}\text { I think the above Glo Data celebrity endorser is highly } \\
\text { credible }\end{array}$ & 13 & 6.8 & 15 & 7.8 & 34 & 18 & 87 & 45.3 & 43 & 22.4 & 3.56 & 1.081 \\
\hline $\begin{array}{l}\text { I think the above Pepsi Cola celebrity endorser is highly } \\
\text { credible }\end{array}$ & 14 & 7.8 & 14 & 7.8 & 35 & 19.6 & 90 & 50.3 & 26 & 14.6 & 3.56 & 1.081 \\
\hline $\begin{array}{l}\text { I believe every word about Glo Data spoken by the } \\
\text { above celebrity endorser }\end{array}$ & 16 & 8.3 & 42 & 21.9 & 51 & 26.6 & 65 & 33.9 & 18 & 9.4 & 3.14 & 1.119 \\
\hline $\begin{array}{l}\text { I believe every word about Pepsi Cola spoken by the } \\
\text { above celebrity endorser }\end{array}$ & 21 & 11.7 & 30 & 16.8 & 43 & 24.0 & 69 & 38.5 & 16 & 8.9 & 3.16 & 1.167 \\
\hline $\begin{array}{l}\text { I accept words of endorsement about Glo Data from my } \\
\text { favorite celebrity as a testimonial }\end{array}$ & 21 & 10.9 & 36 & 18.7 & 44 & 22.9 & 70 & 36.5 & 21 & 10.9 & 3.18 & 1.185 \\
\hline $\begin{array}{l}\text { I accept words of endorsement about Pepsi Cola from } \\
\text { my favorite celebrity as a testimonial }\end{array}$ & 12 & 6.7 & 30 & 16.7 & 41 & 22.9 & 77 & 43.0 & 19 & 10.6 & 3.36 & 1.083 \\
\hline $\begin{array}{l}\text { I think the advertisement message about Glo Data by } \\
\text { the celebrity endorser is sincere }\end{array}$ & 25 & 13.0 & 24 & 12.5 & 42 & 21.9 & 71 & 37.0 & 30 & 15.6 & 3.30 & 1.249 \\
\hline $\begin{array}{l}\text { I think the advertisement message about Pepsi Cola by } \\
\text { the celebrity endorser is sincere }\end{array}$ & 17 & 9.5 & 17 & 9.5 & 41 & 22.9 & 80 & 44.7 & 24 & 13.4 & 3.43 & 1.131 \\
\hline $\begin{array}{l}\text { I feel the Glo Data celebrity endorser is a trustworthy } \\
\text { person }\end{array}$ & 17 & 8.9 & 18 & 9.4 & 53 & 27.6 & 72 & 37.5 & 32 & 16.7 & 3.44 & 1.142 \\
\hline $\begin{array}{l}\text { I feel the Pepsi Cola celebrity endorser is a trustworthy } \\
\text { person }\end{array}$ & 12 & 6.7 & 15 & 8.4 & 50 & 27.9 & 88 & 49.2 & 14 & 7.8 & 3.43 & .988 \\
\hline Total & & & & & & & & & $\begin{array}{l}\text { Glo } \\
\text { Pepsi }\end{array}$ & & $\begin{array}{l}3.32 \\
3.38\end{array}$ & \\
\hline
\end{tabular}

Source: Researcher's Computation, 2017

Table 6: Perceived Expertise of Glo/Pepsi Celebrity Endorser

\begin{tabular}{|c|c|c|c|c|c|c|c|c|c|c|c|c|}
\hline \multirow[b]{2}{*}{ Statement } & \multicolumn{2}{|c|}{ SD } & \multicolumn{2}{|c|}{ D } & \multicolumn{2}{|c|}{$\mathbf{U}$} & \multicolumn{2}{|l|}{$\mathbf{A}$} & \multicolumn{2}{|c|}{ SA } & \multirow[b]{2}{*}{ Mean } & \multirow[b]{2}{*}{ Std Dev. } \\
\hline & Freq & $\%$ & Freq & $\%$ & Freq & $\%$ & Freq & $\%$ & Freq & $\%$ & & \\
\hline $\begin{array}{l}\text { I value the experience of the Glo Data celebrity } \\
\text { endorser }\end{array}$ & 15 & 7.8 & 21 & 10.9 & 37 & 19.3 & 82 & 42.7 & 37 & 19.3 & 3.55 & 1.150 \\
\hline $\begin{array}{l}\text { I value the experience of the Pepsi Cola celebrity } \\
\text { endorser }\end{array}$ & 17 & 9.5 & 18 & 10.1 & 28 & 15.6 & 89 & 49.7 & 27 & 15.1 & 3.61 & 1.122 \\
\hline $\begin{array}{l}\text { I believe that Glo Data celebrity endorser has good } \\
\text { knowledge of the data-plan being endorsed }\end{array}$ & 14 & 7.3 & 22 & 11.5 & 27 & 14.1 & 86 & 44.8 & 43 & 22.4 & 3.64 & 1.163 \\
\hline $\begin{array}{l}\text { I believe that Pepsi Cola celebrity endorser has good } \\
\text { knowledge of the brand being endorsed }\end{array}$ & 8 & 4.5 & 12 & 6.7 & 27 & 15.1 & 82 & 45.8 & 50 & 27.9 & 3.86 & 1.043 \\
\hline $\begin{array}{l}\text { I think the Celebrity Endorser for Glo Data has the } \\
\text { required expertise to advertise the package }\end{array}$ & 9 & 4.7 & 15 & 7.8 & 29 & 15.1 & 92 & 47.9 & 47 & 24.5 & 3.80 & 1.046 \\
\hline $\begin{array}{l}\text { I think the Celebrity Endorser for Pepsi Cola has the } \\
\text { required expertise to advertise the brand }\end{array}$ & 12 & 6.7 & 10 & 5.6 & 20 & 11.2 & 86 & 48.0 & 51 & 28.5 & 3.86 & 1.100 \\
\hline $\begin{array}{l}\text { I think Glo Data celebrity endorser has the right skills } \\
\text { to advertise the data plan }\end{array}$ & 12 & 6.3 & 13 & 6.8 & 22 & 11.5 & 95 & 49.5 & 50 & 26.0 & 3.82 & 1.088 \\
\hline $\begin{array}{l}\text { I think Pepsi Cola celebrity endorser has the right } \\
\text { skills to advertise the brand }\end{array}$ & 7 & 3.9 & 9 & 5.0 & 21 & 11.7 & 95 & 53.1 & 47 & 26.3 & 3.93 & .966 \\
\hline Total & & & & & & & & & $\begin{array}{c}\text { Glo } \\
\text { Pepsi }\end{array}$ & & $\begin{array}{l}3.70 \\
3.81\end{array}$ & \\
\hline
\end{tabular}

Table 7:

\begin{tabular}{lcccc}
\hline Model & R & R Square & Adjusted R Square & Std. Error of the Estimate \\
\hline 1 & $593^{\text {a }}$ & .352 & .343 & .727 \\
\hline
\end{tabular}
a. Predictors: (Constant), CRE, CCO, PSC, CEX, CTR

Table 4.17: ANOVA $^{a}$

\begin{tabular}{|c|c|c|c|c|c|c|}
\hline Model & & Sum of Squares & Df & Mean Square & $\mathbf{F}$ & Sig. \\
\hline \multirow{3}{*}{1} & Regression & 104.684 & 5 & 20.937 & 39.614 & $.000^{\mathrm{b}}$ \\
\hline & Residual & 192.910 & 365 & .529 & & \\
\hline & Total & 297.594 & 370 & & & \\
\hline
\end{tabular}

Table 4.18: Coefficientsa

\begin{tabular}{|c|c|c|c|c|c|c|}
\hline \multirow{2}{*}{\multicolumn{2}{|c|}{ Model }} & \multicolumn{2}{|c|}{ Unstandardized Coefficients } & \multirow{2}{*}{$\begin{array}{c}\text { Standardized Coefficients } \\
\text { Beta }\end{array}$} & \multirow[b]{2}{*}{$\mathbf{T}$} & \multirow{2}{*}{ Sig. } \\
\hline & & B & Std. Error & & & \\
\hline 1 & (Constant) & .144 & 251 & & .574 & .567 \\
\hline & PSC & .164 & .055 & .149 & 2.994 & .003 \\
\hline & CTR & .271 & .061 & .242 & 4.413 & .000 \\
\hline & CEX & .085 & .056 & .078 & 1.522 & .129 \\
\hline & $\mathrm{CCO}$ & -.012 & .067 & -.008 & -.175 & .861 \\
\hline & CRE & .340 & .054 & .310 & 6.319 & .000 \\
\hline
\end{tabular}

